УДК $007: 304: 070+659.3$

\title{
FEATURES OF THE 1993 INTERVIEW WITH THE KINOKURER NEWSPAPER
}

\author{
Hanna Kholod, \\ candidate of philological sciences, \\ ResearcherID: $A A D-5685-2020$ \\ https://orcid.org/0000-0002-2479-9721 \\ kholodanna@ukr.net, \\ Director of the Public Organization \\ Scientific and educational center "SUCCESSFUL", \\ 03148, Ukraine, Gnat Yura, 3, of. 44.
}

Problem. The article is a continuation of the study of the processes of decanonization of the interview genre in the early 1990s. It clarifies the specifics of the interviews published in the newspaper "Kinokurer" (1993), through the analysis of materials at the semantic, compositional, figurative, linguistic, paralinguistic levels.

Methodology. The descriptive method allowed to record everything that is needed to cover the research topic. Analysis and synthesis contributed to the formation of a holistic view of the specifics of the content, composition, design, image system of interviews published in the newspaper "Kinokurer" (1993). The object of the research is an interview in the newspaper "Kinokurer" (1993). The subject of the research is the specifics of the interview in the newspaper "Kinokurer" (1993). The purpose of the study is to find out the peculiarities of the interview in the newspaper "Kinokurer" (1993).

Conclusions. Thus, in the newspaper "Kinokurier" (1993), in addition to classic interviews with different compositional variability and interviews-monologues, journalistic texts are used, in which the interview is dominant and which have the following modifications: genre combination, genre conglomerate, genre inlay, contributing to the maximum presentation of the image of the interviewee on the semantic, compositional, speech, paralinguistic levels. In journalistic texts, where there are interviews of foreign origin and textual additions of domestic journalists, the range of disclosure of the image of the interviewee increases due to the intercultural component.

Key words: interviewer, interviewee, journalistic text, compositional elements, contamination.

\section{ОСОБЛИВОСТІ ІНТЕРВ’Ю В ГАЗЕТІ “КІНОКУР'СР” ЗА 1993 РІК}

\author{
Ганна Холод, \\ кандидат філологічних наук, \\ директор Громадської організаиї \\ "Науково-освітній иентр "УСПІШНИЙ” \\ (м. Київ, Україна).
}

\section{Вступ}

У попередній статті, надрукованій у журналі “Соціальні комунікації: теорія та практика" (№ 10, 2020), було згадано про деканонізацію жанрів, притаманну жанровій системі журналістики в 90-х роках $\mathrm{XX}$ століття. Вищезгадане явище потребує термінологічного обгрунтування й створення класифікації, що презентувала б розмаїття 
жанрових експериментів того часу. У вищезазначеній статті було зроблено спробу узагальнити результати практичної реалізації творчого потенціалу журналістів у царині такого жанру, як інтерв'ю. Ця робота є продовженням дослідження специфіки інтерв'ю в газеті “Кінокур'єр”, однак у центрі нашої дослідницької уваги будуть матеріали, надруковані в газеті “Кінокур'єр” за 1993 рік.

\section{Методи та методики дослідження}

Описовий метод дозволив зафіксувати все, що потрібно для висвітлення теми дослідження.

Аналіз та синтез сприяли формуванню цілісного уявлення щодо специфіки контенту, композиції, оформлення, образної системи інтерв'ю, розміщених у газеті “Кінокур'єр” (1993).

Для досягнення поставленої мети було виконано таку процедуру:

1. У газеті “Кінокур'єр” (1993) для аналізу було обрано класичні інтерв’ю й журналістські тексти, домінантним у яких є інтерв’ю.

2. Було проаналізовано змістовий, композиційний, образний, жанровий, мовний, паралінгвістичний рівні вищезазначених текстів.

Об'єкт дослідження - інтерв'ю в газеті “Кінокур'єр” (1993 рік).

Предмет дослідження - специфіка інтерв'ю в газеті “Кінокур'єр” (1993 рік).

Мета дослідження - з’ясування особливостей інтерв’ю в газеті “Кінокур’єр” (1993 рік).

\section{Результати та дискусії}

Інтерв’ю в газеті “Кінокур'єр” за 1993 рік розміщено в таких рубриках: “Зустрічі для вас", “Актори ближнього зарубіжжя в наших фільмах", “Актори ближнього зарубіжжя”, "Гості з берегів Неви", "Кіноактори України", "Московські зірки на нашому небосхилі", “Олімп”, "Професія: режисер”, “Кіноактори України”, “Новини знімальних майданчиків”, “Кіномитці України”, “Інтерв”ю в номер”, “Перші кроки”, “Зустрічі для вас”, “Гості вітальні “Кінокур'єра"”, “Звёзды России”, “Зустрічі у вітальні "Кінокур'єра"”, "Наша презентация", "На пути к экрану”, “Гості вітальні” - та підрубриках: “Бенефіс! Бенефіс! Бенефіс!”, “Интервью со звездой”, “Династии”, “Поштова скринька", "Наедине с “секс-символом”", “Монолог для читача", “Секс - дело серьёзное!”, “Майстрині”, “Наодинці з усіма”, “Зустрічі для вас", “Автопортрет без гриму”, "Интервью в постели” (назву розміщено на білій плашці 3 відеокамерою), "Вместо исповеди" (назву оформлено на плашці зі світлим тлом, на якому намальовано відеокамеру), “Автопортрет без інтер'єру”, “Монолог для читачів”, “Медитативный перебор бусинок”, “Первый украино-американский фильм”, “Ретро”, “Звездный час".

В інтерв”ю, надрукованих у газеті “Кінокур'єр” за 1993 рік, переважно висвітлено фрагменти біографії акторів, розвиток їхньої кар'єри, іноді у вищезазначеному жанрі презентовано негативне ставлення кінофахівців до державної політики щодо української культури, зокрема кіно, яке перебувало в періоді стагнації через несприятливі економічні умови, від імені кінорежисера-інтерв'юйованого дано рекомендації майбутнім кінорежисерам, кінофахівцями-інтерв'юйованими сформульовано відповіді на запитання читачів.

Як правило, заголовки інтерв'ю оформлено таким чином, щоб привернути до вищезгаданого жанру увагу читачів за допомогою шрифтів (прямий та курсив різної насиченості), колористичного оформлення (зелений, чорний, червоний кольори). Часто 
заголовки мають дві частини, оформлені різними кольорами (чорний та зелений, чорний та червоний).

Переважно заголовки інтерв'ю мають дві частини: ім'я та прізвище інтерв'юйованого, трансформоване висловлювання інтерв'юйованого, оформлене в лапках, які мають різні варіанти графічної (прямий жирний шрифт, прямий жирний шрифт - жирний шрифт курсивом, прямий жирний шрифт - розміщення висловлювання на плашці сірого кольору) та колористичної (чорний колір - зелений колір, чорний колір - червоний колір, чорний колір синій колір) презентації. Ступінь трансформації висловлювання інтерв'юйованого різний: зміна одного слова (заголовок “Доброта - це найсвятіше!” (Кочевська-а, 1993) - речення в інтерв'ю “Доброта - це найголовніше” (Кочевська-а, 1993)), додавання одного слова (заголовок “Я повністю в руках фортуни” (Чернова, 1993) - речення в інтерв'ю “Повністю у руках долі, фортуни” (Чернова, 1993)), вилучення слова (заголовок “Сергей Жигунов: Счастье для меня - преодоление!” (Плетинко-г, 1993) - речення в інтерв”ю “Для меня счастье - это преодоление чего-либо" (Плетинко-г, 1993)), повна трансформація (заголовок “Джек Николсон: “Я - шут!”” (Джек Николсон..., 1993) - речення в інтерв”ю (“Мы придумали слово “шутовник” от “шута"” (Джек Николсон..., 1993). Деякі заголовки із зазначеною вище двохелементною композицію мають другу частину, не оформлену в лапках (Софи Марсо: Люблю танец, ветер, солнце! (Софи Марсо..., 1993)).

У газеті “Кінокур'єр” (1993) є невелика кількість інтерв’ю, що претендують на класичність і мають такі композиційні елементи:

1.Вступна частина, у якій інтерв'юер пояснює причину проведення інтерв'ю (наявність неякісної кінематографічної продукції молодих кінорежисерів, зацікавленість долею молодих кінорежисерів читачами газети), основна частина (Бут-б, 1993).

2.Вступна частина, у якій інтерв'юер презентує інтерв'юйовану за допомогою розповідних і питальних речень, основна частина (Косничук-в, 1993).

3.Вступна частина інтерв'ю, у якому зазначено результат творчої діяльності кінорежисера, основна частина, заключна частина (Цибулько, 1993).

4.Є вступна частина, виділена курсивом, у якій ідеться про причини проведення інтерв'ю, пов'язані зі стагнацією українського кіно та пошуками виходу зі скрутної ситуації, організаційні умови проведення інтерв’ю, основна частина та заключна, представлена непрямою мовою - відповіддю на запитання журналіста й риторичним запитанням щодо програми розвитку українського кіно (Косничук-г, 1993).

5.С виділена курсивом вступна частина, у якій презентовано актора, основна частина (Віктор Степанов..., 1993).

Інтерв'ю, крім вищезазначених, переважно притаманна контамінаційність, презентована різноманітними варіантами:

1. Жанрова інкрустація (вкраплення (невеликі за обсягом, як правило, мають обрамлення) в один жанр елементів іншого жанру).

У вступній частині інтерв”ю “Любов Поліщук: “Доброта - це найсвятіше!'” $є$ елементи портретного нарису (Кочевська-а, 1993).

У виділеній жирним шрифтом вступній частині $є$ замітка про номінацію Борислава Брондукова на Шевченківську премію й інформація про те, що інтерв'юйованою є його дружина, мета спілкування з якою - дізнатися інформацію про Б. Брондукова (Косничук-а, 1993).

У вступній частині інтерв'ю є елементи репортажу (Кочевська-б, 1993).

2. Серед журналістських текстів, у яких домінантним є інтерв’ю, можемо виокремити жанровий конгломерат (поєднання жанрів різних груп зі збереженням їхньої жанрової специфіки й чітко окресленими межами), що має такі варіанти: 
2.1. Наприклад, у журналістському тексті “Объяснение в любви” $є$ дві частини (“Маргарита на балу”, “Маргарита после бала”), що мають заголовки. I частина, виділена жирним шрифтом й оформлена нахилом, - замальовка події - балу Маргарити, що відбувся 4 грудня 1992 року в Домі кінематографістів за участю Маргарити Кринициної. II частина інтерв'ю, що має вступну частину, де інтерв'юер розповідає про нетрадиційні умови спілкування ("Поэтому эксклюзивное интервью было что называется на ходу, почти в танце..." (Денис, 1993)) під час інтерв’ю, що разом із вищезгаданою подією зумовило появу нових найменувань інтерв'юера та інтерв'юйованого (партнер - інтерв'юер, королева заслужена артистка України Маргарита Криницина), та основну частину, що містить запитання, виділені жирним накресленням, і відповіді.

2.2. Портретний нарис й інтерв'ю (Марина Могилевська..., 1993).

2.3. Міні-замальовка, побудована за допомогою апокризи (запитання - відповідь) і градації питальних речень, й основна частина інтерв'ю (Косничук-г, 1993).

2.4. Міні-кінорецензія, виділена курсивом і графічно відділена від інтерв'ю, й інтерв'ю, що має вступну частину та основну частину (Тарасова, 1993).

2.5. Портретний нарис й основна частина інтерв'ю (Л (нерозбірливо), 1993).

2.6. Замальовка про долю українського кінематографа з елементами творчої біографії Вікторії Корсун й основна частина інтерв'ю (Е.К., 1993).

3. Серед журналістських текстів, у яких домінантним є інтерв'ю, можемо виокремити жанрову комбінацію (поєднання жанрів зі збереженням жанрових особливостей у межах однієї групи жанрів). В інтерв'ю “Степан Олексенко: за мистецтво треба боротися!” (Олексієнко, 1993) є замітка про творчість митця.

3.1. У тексті “Сукні для королеви” $\epsilon$ репортаж, в останньому реченні якого $\epsilon$ апосиопеза, що 3 огляду на контекст виконує функцію вираження емоції журналіста (“...нарешті, коли трохи отямився від такої краси, видавив 3 себе я” (Глоба-в, 1993)), й інтерв’ю, що містить лише основну частину.

3.2. В інтерв'ю з Дмитром Харатьяном є деякі особливості: поєднання таких форматів “запитання інтерв”юера+відповіді інтерв”юйованого, “відповідь без запитання інтерв'юера”, на основі якої можна реконструювати запитання інтерв'юера, + коментар інтерв'юера”, “запитання інтерв’юера+відповідь інтерв’юйованого+коментар інтерв’юера”, ““відповідь без запитання інтерв'юера”. Крім цього, є композиційне обрамлення, представлене фрагментами, яким притаманна репортажність (“Йому в цьому січні - 33. Але все одно поряд зі мною сидить вихованець та душа компанії піонерського табору 60-70 років, відчуваю ту дорослість, гітару, світле волосся, тільки додайте гарну суміш, названу чаєм, виготовлену у тонательє кіностудії') (Чернова, 1993).

3.3. В інтерв”ю “Сергей Жигунов: Счастье для меня - преодоление. Интервью. Дубль первый” I частина, містячи підзаголовок із жанровим визначенням "Интервью. Дубль первый”, має жанрові ознаки репортажу, у якому йдеться про емоції, враження, почуття журналістки перед зустріччю з кіноактором і під час інтерв'ю з ним. Ця частина є логічно завершеною, про що свідчить запис "С Сергеем Жигуновым встречалась Лариса Плетинко" (Плетинко-г, 1993). Постскриптум (“Стенограмму диалога прилагаю. Финальную тему умышленно упускаю. С неё мы начнём наш следующий разговор с Жигуновым” (Плетинког, 1993)) є логічним переходом до другої частини, яка містить інтерв'ю й графічно відділена від першої частини лінією сердечок.

3.4. Замітку розміщено під заголовком і графічно відділено від основної частини інтерв'ю, після якого інтерв'юйованим написано побажання (Плетинко-в, 1993).

3.5. Інформаційну замітку виділено курсивом і графічно не відділено від інтерв'ю (Плетинко-а, 1993). 
3.6. Замітку про специфіку роботи з листами виділено курсивом, потім розміщено монолог кінорежисера Миколи Вікторовича Засєєва щодо ситуації 3 кінокомпанією й графічно відокремлений діалог інтерв’юера Н. Бут із кінорежисером (Бут-г, 1993).

С журналістські тексти, що містять інтерв'ю закордонного журналіста, про що свідчать такі маркери (“С Изабель Аджани беседовал кореспондент журнала "Пари Матч”. Представляем несколько фрагментов интервью” (Изабель Аджани..., 1993); “С ней разговаривает корреспондент журнала "ПАРИ МАТЧ” (Ким Новак..., 1993), інформація про те, що Олег Просихин є ведучим рубрики “Олімп”, де розміщено матеріали зарубіжної преси), та чужий текст, створений журналістом газети “Кінокур'єр” і презентований такими варіантами:

1. Творчою біографією, оформленою курсивом і графічно відділеною від інтерв’ю (Изабель Аджани..., 1993; Ким Новак..., 1993; Мітхун..., 1993).

2. Заміткою про творчість, оформленою курсивом і графічно відділеною від інтерв'ю (Девушка..., 1993).

3. Інтерв'ю з Джеком Ніколсоном, запозиченим із закордонної преси, притаманна варіативність (графічно відокремлена й виділена курсивом замітка про творчість, написана вітчизняним журналістом, інтерв'ю з міні-нарисом, автором якого $\epsilon$ закордонний журналіст; написаний вітчизняним журналістом міні-нарис, що $є$ обрамленням для основної частини інтерв'ю), що виникає через відсутність інформації про авторство заключної частини тексту (Джек Николсон..., 1993).

4. Заміткою про епатажні вчинки Демі Мур, Бріджет Нільсен щодо опублікування фотографій з оголеними та вагітними актрисами (Откровения..., 1993), написаною вітчизняним журналістом, прізвище якого не зазначено, потім текстом закордонного журналіста, що містить інформацію щодо особистого життя, яка продовжується словами Бріджит про перший шлюб, оформленими як репліка діалогу. Особливістю цього інтерв’ю, що має заключну частину, є те, що відповідь на запитання дають Бріджит Нільсен та Рауль Майер.

Слід зазначити, що в газеті “Кінокур'єр” є журналістські тексти, у яких домінантними є інтерв'ю-монологи і які мають такі варіанти оформлення.

1. Інтерв'ю з Іриною Алфьоровою (Ирина Алфёрова, 1993) має дві частини. І частина текст, виділений чорним жирним шрифтом і графічно відділений від інтерв'ю, 3 елементами замальовки, у якій є багато запитань, окличних речень, апосиопез. Припускаємо, що цю частину писав Євгеній Луценко, прізвище якого розміщено наприкінці всього журналістського тексту. II частина містить 5 текстів із заголовками. Маркерами інтерв'ю в ньому є наявність тире на початку реплік. Усі заголовки мають песимістичну тональність, репрезентують самотність, внутрішню спустошеність інтерв'юйованої через відсутність можливості самореалізуватися.

2. Монолог-інтерв’ю з Леонідом Філатовим складається з 11 частин, які мають назви, переважно презентовані називним непоширеним реченням, що дозволяють реконструювати запитання журналіста. Його маркером присутності є ініціали та прізвище під інтерв'ю (Бут-в, 1993).

3. У монолозі-інтерв’ю з Іриною Терещенко (Косничук-б, 1993) є маркери діалогу (репліки починаються 3 тире), а також монологу - зазначення виду мовлення "монолог записала Е. Косничук” (Косничук-б, 1993). Назви частин тексту (“Спочатку вмерла..." (Косничук-б, 1993), “А потім - ожила...” (Косничук-б, 1993), “На семи вітрах...” (Косничукб, 1993), “Підказка з космосу...” (Косничук-б, 1993), “Світ-таки не без добрих людей” (Косничук-б, 1993), “Три “Д”” (Косничук-б, 1993), “Але бувають такі моменти” (Косничук-б, 1993)) не дають можливості відтворити запитання журналіста, крім однієї назви "Що я робитиму ще” (Косничук-б, 1993). Дві останні частини під назвами (“Що я робитиму ще” 
(Косничук-б, 1993), “Але бувають такі моменти” (Косничук-б, 1993)) не є логічним продовженням попереднього тексту, який, на нашу думку, є суцільним монологом і штучно був поділений на частини.

4. У журналістському тексті “Монолог Примадонны, услышанный в отрывках", що містить репортажні елементи (початок тексту, у якому йдеться про умови проведення інтерв’ю, свідком якого стала Лариса Плетинко, а також середина монологу-інтерв'ю (спостереження Лариси Плетинко за чоловіком Ірини Метлицької, який на деякий час своєю появою зупинив інтерв'ю)), основною частиною $є$ монолог - результат трансформації інтерв'ю, зумовленої необхідністю гостя-журналіста, який був свідком інтерв'ю, виходити 3 кімнати. (“Современный гость должен уметь все: мне пришлось подсуетиться по части кофе и бутерброда - несколько раз я выходила в буфет и смогла услышать только отдельные куски искреннего монолога актрисы" (Плетинко-б, 1993)). Його маркерами є апосиопези, які чітко окреслюють початки реплік інтерв'юйованої.

Використано три ситуативні фотографії, які розташовано горизонтально й нерозривно й на яких зафіксовано інтерв'юйовану Маргариту Криницину в різних ролях і 3 різною мімікою, що підкреслює їі акторський талант уживання в роль (Денис, 1993).

В інтерв'ю з Любов'ю Поліщук їі фотографія контрастує з образом життєрадісної жінки, створеним у портретному нарисові (“Коли Люба з'явилася на знімальному майданчику, все ніби посвітліло навколо. Струнка, елегантна, з сліпучою білозубою усмішкою, сяйвом променистих очей, вона ніби осявала всіх аурою жіночності, привабливості, краси” (Кочевська-а, 1993)), що є елементом вступної частини інтерв’ю, та інтерв’ю, де є ремарки “При цьому Люба дзвінко сміється” (Кочевська-а, 1993); “сміється” (Кочевська-а, 1993) і позитивно марковані (“радість" (Кочевська-а, 1993), “кохання" (Кочевська-а, 1993), “любов” (Кочевська-а, 1993), “доброта” (Кочевська-а, 1993), “удача” (Кочевська-а, 1993), “надія” (Кочевська-а, 1993), “щаслива” (Кочевська-а, 1993) слова.

В інтерв’ю з Катериною Брондуковою є чотири фотографії: портретна фотографія Катерини Брондукової й три вертикально розташовані фотографії кадрів із фільмів (“Камяний хрест”, “Комісари”, “Вавілон-ХХ”), де крупним планом зображено Б. Брондукова (Косничук-а, 1993).

В інтерв’ю з Дмитром Харатьяном використано одну ситуативну фотографію. Через відсутність текстівки під фотографією можемо лише припустити, що це фотографія епізоду фільму (Чернова, 1993).

В інтерв'ю 3 Амандою Сандреллі використано дві іï фотографії (у розташуванні $є$ елементи колажування), що, підкреслюючи сексуальність інтерв'юйованої, не корелюють зі змістом інтерв'ю (Девушка..., 1993).

В інтерв'ю з Ізабель Аджані використано фотографію епізоду фільму з текстівкою “На снимке - Изабель Аджани в облике Скарлетт O’Хары, героини “Унесенных ветром"” (Изабель Аджани..., 1993).

Фотографія Сергія Жигунова, що репрезентує імпозантного та привабливого чоловіка, корелює лише з назвою підрубрики “Наедине с “секс-символом"”, а не з інтерв”ю (Плетинког, 1993).

У газеті “Кінокур'єр" є інтерв”ю без назви, розміщене в рубриці “Новини по телефону” (Наталі Сгоровій..., 1993). У ньому є два обрамлені заміткою запитання розвідувального характеру, одне 3 яких виділено жирним накресленням. Під інтерв'ю розташовано фотографію епізоду фільму 3 текстівкою над нею "На знімку Георгія Скачка - Наталя Сгорова у фільмі “Жінка для всіх” (режисер А. Матешко)”.

В інтерв'ю “Сукні для королеви” під текстом розміщено велику за розміром фотографію, на якій актриси одягнені в гарні сукні (Глоба-в, 1993). 
В інтерв”ю “Леонід Філатов про себе” є фотографія актора, на якій зображено жест закритості, зокрема складені на грудях руки в замок, на тлі іншої людини, в очах у Філатова $\epsilon$ сум. Фотографія корелює 3 текстом інтерв'ю, тому що в ньому інтерв'юйований наголошує, що друзів перевіряє час, Філатов не задоволений розмежуванням людей, пріоритетом меркантильних інтересів, що впливають на людські стосунки (“Зараз на перший план вийшли гроші. Люди відокремлюються один від одного, діляться на правих і лівих, росіян і неросіян” (Бут-в, 1993)).

В інтерв’ю “Алла Волошина: Без живой веры в Бога мы подобны разноцветному окну в темноте... " є фотографія Алли Волошиної, що корелює з образом інтерв'юйованої, зокрема зі словами ("На её глазах грусть, а на лице добрая улыбка" (Кучерявый, 1993)). Фотографія сумної Алфьорової корелює зі змістом інтерв’ю (Ирина Алфёрова, 1993).

Фотографія Сумської, що презентує образ сексуальної героїні фільму “Декамерон”, в інтерв’ю “Ольга Сумская: Я испытала оргазм души!” не корелює зі змістом проведеного бліц-опитування (Косничук-д, 1993).

В інтерв’ю “Софи Марсо: Люблю танец, ветер, солнце!” (Софи Марсо..,, 1993) використано дві фотографії. Ідеться про фотографію епізоду з фільму "Мои ночи лучше ваших дней”, де зображено оголену актрису, і фотографію з буденного життя.

Фотографія Кім Новак, на якій презентовано iї молодий образ, не корелює з реальним віком актриси (60 років), у якої беруть інтерв’ю (Ким Новак..., 1993).

У газеті “Кінокур'єр" є фотографії, на яких зображено оголених жінок. Наприклад, в інтерв'ю “Откровения Венеры” (Откровения..., 1993) є дві фотографії. На одній фотографії сім'я, де хлопчик слухає живіт матері, яку обіймає чоловік, на іншій фотографії - син та Бріджит оголені. Отже, є портретні фотографії інтерв'юйованих, а також фотографії, у яких вони презентовані або в сценічних (Кочевська-б, 1993), або кінематографічних (Віктор Степанов, 1993; Глоба-б, 1993) образах.

Необхідно зазначити, що інтерв”ю “Объяснение в любви” (Денис, 1993), яке взяли в актриси Маргарити Кринициної і яке не має на меті зібрати інформацію щодо чітко визначеного предмета розмови, притаманна різновекторність запитань щодо господарства, особистого життя, професії, філософського погляду на життя, специфіки відновлення своєї енергетики. Під час інтерв'ю інтерв'юйована використовує лексеми та речення, які $\epsilon$ маркерами іiі ставлення до економічної ситуації, що склалася в 90-х роках XX століття у зв'язку з трансформаційними процесами в суспільно-політичному й культурному житті країни. Зокрема, лексеми презентують труднощі адаптивного періоду й мають негативну конотацію (“Одеваюсь от случая к случаю. Удалось что-то купить - одеваю. Нет - как все. Иногда и хуже” (Денис, 1993) “Я прихожу к выводу, что сейчас очень-очень плохо” (Денис, 1993)).

У деяких інтерв'ю спостерігаємо несприйняття інтерв'юйованими епістеми трансформаційного часу (“Набридла до одуріння оця чорнуха, порнуха, яка пролізла скрізь. Хочеться нормальних людських відносин. I на екрані. I в житті” (Кочевська-а, 1993). "Поперше, мені хочеться, щоб всі близькі, рідні мені люди були живими і здоровими. По-друге, хочеться, щоб моя рознещасна країна, нарешті, прийшла до нормального життя, на яке вона так заслуговує, і, по-третє, дуже хочеться побувати в Парижі...” (Кочевська-а, 1993); "Прочитавши листа, я відчув тривогу й смуток. Тривогу за те, що сьогодні ровесники Руслана стають неприкаяними, а смуток - ми нічим суттєвим не можемо їм допомогти” (Глоба-а, 1993)).

Завдяки окличним реченням, градації питальних речень чітко окреслено критичну позицію інтерв’юйованого (Л (нерозбірливо), 1993) щодо державної політики у сфері кіно, дискредитації поняття “режисер”. 
Інтерв’ю притаманні “розвивальне” (Лукина, 2003), “уточнювальне” (Лукина, 2003) (“Вы потеряли её?” (Изабель Аджани, 1993)), “гіпотетичне” (Лукина, 2003) запитання (“А куди понесе Вас кінематографічна фортуна найближчим часом?” (Марина Могилевська, 1993), “А как бы Вы распорядились своим будущим, если бы Вашим отцом был Керк Дуглас?” (Живая легенда..., 1993), “перехідні” запитання (Лукина, 2003), які змінюють напрямок бесіди, “перенавантажені” (Лукина, 2003) запитання (“Ви з радістю прийняли запрошення приїхати до Києва на зйомки? Чим привабила Вас тема нового фільму?” (Кочевська-а, 1993)), “провокативне” (Лукина, 2003) запитання (“Немає що робити? Хіба ви не вважаєте себе професіоналом?” (Чернова, 1993)); провокативні твердження “Берт Ланкастер, котрого Вы, конечно же, хорошо знаете, сказал: "Керк Дуглас - это самый невыдержанный человек..." (Живая легенда, 1993), "Все актеры так говорят. Я Вам не верю" (Живая легенда, 1993) журналіста, який, озвучуючи деталі із життя інтерв’юйованого, спонукає його до відвертості; “мімічне” (Лукина, 2003) запитання, презентоване двома знаками запитання, яке 3 огляду на попередню відповідь інтерв'юйованого, виражає здивування (Тарасова, 1993). Акцент інтерв'юера на міміці інтерв'юйованого Віктора Степанова дозволяє підкреслити динаміку його почуттів (“сяйнув білозубою” (Віктор Степанов, 1993), “сонячною усмішкою артист” (Віктор Степанов, 1993), “посмішка зійшла 3 вуст Віктора Федоровича" (Віктор Степанов, 1993), "гострий розум зробив очі серйознішими” (Віктор Степанов, 1993), “суворішим стало обличчя” (Віктор Степанов, 1993), “на мить замислився і знову вуста торкнула лагідна усмішка” (Віктор Степанов, 1993)).

\section{Висновки}

Отже, у газеті “Кінокур’єр” (1993), крім класичних інтерв’ю з різною композиційною варіативністю й інтерв'ю-монологів, використано журналістські тексти, у яких домінантним є інтерв'ю і які мають такі модифікації: жанрову комбінацію, жанровий конгломерат, жанрову інкрустацію, що сприяють максимальній презентації образу інтерв'юйованого на змістовому, композиційному, мовленнєвому, паралінгвістичному рівнях. У журналістських текстах, де $є$ інтерв'ю закордонного походження й текстові доповнення вітчизняних журналістів, діапазон розкриття образу інтерв'юйованого збільшується завдяки міжкультурному компонентові.

\section{Література}

Бут Н. (а) Леонід Філатов про себе. Кінокур’єр. 1993. №7-8. 6.

Бут Н. (б) “Дебют” - наша надія чи шок? Кінокур’єр. 1993. №11 - 12. 3.

Бут Н. (в) Леонід Філатов про себе. Кінокур’єр. 1993. №7-8. 6

Бут Н. (г) Так далі жити не можна! Кінокур’єр. 1993. № 5. 2.

Віктор Степанов у фільмі “Таємниця Вілли”. Кінокурєр. 1993. № 5. 6.

Глоба Г. (а) Анатолій Матешко: Що бентежить твоє серце... Кінокур’єр. 1993. №3. 3.

Глоба Г. (б) Віктор Степанов Громадянином планети я б став з радістю. Кінокур'єр. 1993. №5. 6.

Глоба Г. (в) Сукні для королеви. Кінокур’єр. 1993. №6. 4.

Девушка с кошачьими глазами. Кінокур’єр. 1993. №2 (9). 7.

Денис. Объяснение в любви. Кінокур’єр. 1993. №1. 4.

Джек Николсон: “Я - шут!”’. Кінокур’єр. 1993. №3 (10). 7.

Е.К. Все, що знаходиш, треба втрачати? Кінокур’єр. 1993. №7-8. 5.

Живая легенда Голливуда. Кінокур’єр. 1993. №3. 8. 
Изабель Аджани. Кінокур’єр. 1993. №2 (9). 7.

Ирина Алфёрова: “Никому до меня нет дела!” Кинокур’єр. 1993. № 15-16 (22-23). 6.

Ким Новак: Я всегда боялась людей. Кінокур’єр. 1993. № 9-10. 5.

Косничук Е. (а) Борислав Брондуков очима Каті Брондукової. Кінокур’єр. 1993. №2. 4.

Косничук Е. (б) Воскресіння. Кінокур'єр.1993. № 9-10. 6.

Косничук Е. (в) Ірина Мельник: Мені подобається бути ніжною. Кінокур’єр. 1993. №4 (11). 5.

Косничук Э. (г)“Ітmpex groop - энергия, сила, решительность” Кінокур’єр. 1993. №9-10. 3.

Косничук Э.(г) Несколько любовных историй. Кинокур’єр. 1993. №6. 2.

Косничук Э. (д) Ольга Сумская: Я испытала оргазм души. Кинокур'єр. 1993. 23). 3.

Кочевська Л.(а) Любов Поліщук: “Доброта - це найсвятіше!” Кинокур’єр. 1993. №1 (8). 5.

Кочевська Л. (б) Михайло Свєтін: Я виріс на Бесарабці. Кінокур'єр. 1993. №11-12. (18-19). 6.

Кучерявый А. Алла Волошина: Без живой веры в Бога мы подобны разноцветному окну в темноте... Кінокур’єр. 1993. №6. 5.

Л (нерозбірливо) Ю. У вирі первісних інстинктів чи гра без правил? Кінокур’єр. 1993. №4. 2.

Лукина, М. (2003). Технология интервью. Москва. Дата звернення 02.08.2020 http://evartist.narod.ru/text5/34.htm

Марина Могилевська: Я ніколи не губилася перед камерою. Кінокур’єр. 1993. №3 (10). 5.

Мітхун: Скільки коханок не рахував. Кінокур’єр. 1993. № 11-12. 8.

Наталі Сгоровій телефонувала Лариса Плетінко. Кінокур’єр. 1993. №2 (9). 5.

Олексієнко Л. Степан Олексенко: за мистецтво треба боротися! Кінокур’єр. 1993. №3 (10). 5.

Откровения Венеры. Кінокур’єр. 1993. №. 9-10. 4.

Плетинко Л. (а) Ивар Калныниш: Я не жду, когда придет депрессия. Кінокур’єр. 1993. № 910. 7.

Плетинко Л.(б) Монолог Примадонны, услышанный в отрывках в гостях у Ирины Метлицкой. Кінокур’єр. 1993. № 13-14. 7.

Плетинко Л. (в) Мэтр литовского кино Регимантас Адомайтис - наш гость. Кінокур'єр. 1993. № 6.5 .

Плетинко Л. (г) Сергей Жигунов: Счастье для меня - преодоление! Дубль первый. Кінокур'єр. 1993. №3 (10). 6.

Софи Марсо: Люблю танец, ветер, солнце! Кінокур’єр. 1993. №9-10. 4.

Тарасова Г. Трамвай удачі. Кінокур’єр. 1993. №6. 4.

Цибулько Р. Геть сором! Кінокур’єр. 1993. №9-10. 2.

Чернова Ю. Дмитро Харатьян: Я повністю в руках фортуни. Кінокур’єр. 1993. №2 (9). 5.

\section{References}

But, N. (a) (1993). Leonid Filatov pro sebe. [But N. Leonid Filatov about himself]. Kinokurier. №78. 6 (in Ukrainian).

But, N. (в) (1993). "Debjut" - nasha nadija chy shok? [But N. "Debut" - our hope or shock?) Kinokurier. №11-12. 3 (in Ukrainian).

But, N. (v) (1993). Leonid Filatov pro sebe. [But N. Leonid Filatov about himself]. Kinokurier. №7-8. 6 (in Ukrainian).

But, N. (h) (1993). Tak dali zhyty ne mozhna! [But N. You can't live like this anymore!) Kinokurier. № 5.2 (in Ukrainian).

Viktor Stepanov u fil'mi "Tajemnycja Villy". [Victor Stepanov in the film "The Secret of the Villa"]. Kinokurier.1993. № 5.6 (in Ukrainian).

Globa, G. (a) (1993). Anatolij Mateshko: Scho bentezhyt' tvoje serce...[Globa G. Anatoliy Mateshko: What confuses your heart...]. Kinokurier. №3. 3 (in Ukrainian). 
Globa, G. (в) (1993). Viktor Stepanov Gromadjanynom planety ja b stav z radistju. [Globa G. Victor Stepanov I would gladly become a citizen of the planet]. Kinokurier. №5. 6 (in Ukrainian).

Globa, G. (v) (1993). Sukni dlja korolevy. [Globa G. Dresses for the queen]. Kinokurier. №6. 4. Devushka s koshach'ymy glazamy. [A girl with cat eyes]. Kinokurier.1993. №2 (9). 7 (in Russian).

Denys. (1993). Ob'jasnenye v ljubvy. [Denis An explanation in love]. Kinokurier. №1. 4 (in Russian).

Dzhek Nykolson: “Ja - shut!’”. [Jack Nicholson: "I'm a jester!"]. Kinokurier.1993. №3 (10). 7 (in Russian).

E.K. (1993). Vse, scho znahodysh, treba vtrachaty? [E.K. Everything you find should be lost?]. Kinokurier. №7-8. 5 (in Ukrainian).

Zhyvaja legenda Gollyvuda. [A living legend of Hollywood]. Kinokurier.1993. №3. 8 (in Russian). Yzabel' Adzhany. [Isabel Ajani]. Kinokurier. 1993. №2 (9). 7 (in Russian) .

Yryna Alfjorova: "Nykomu do menja net dela!" [Irina Alferova: "Nobody cares about me!"]. Kinokurier.1993. № 15-16 (22-23). 6 (in Russian).

Kym Novak: Ja vsegda bojalas' ljudej. [Kim Novak: I've always been afraid of people]. Kinokurier.1993. № 9-10. 5 (in Russian).

Kosnychuk, E. (a) (1993). Boryslav Brondukov ochyma Kati Brondukovoji. [Kosnichuk E. Borislav Brondukov through the eyes of Katya Brondukova]. Kinokurier. №2. 4 (in Ukrainian).

Kosnychuk, E. (b) (1993). Voskresinnja. [Kosnichuk E. Resurrection]. Kinokurier. № 9-10. 6 (in Ukrainian).

Kosnychuk, E. (v) (1993). Iryna Mel'nyk: Meni podobajet'sja buty nizhnoju. [Kosnychuk E. Iryna Melnyk: I like to be gentle]. Kinokurier. №4 (11). 5 (in Ukrainian).

Kosnychuk, E. (h) (1993). "Impex groop - energyja, syla, reshytel'nost"” [Kosnichuk E. "Impex groop - energy, strength, determination"]. Kinokurier. №9-10. 3 (in Russian).

Kosnychuk, E. (g) (1993). Neskol'ko ljubovnyh ystoryj. [Kosnichuk E. Several love stories]. Kinokurier. №6. 2 (in Russian).

Kosnychuk, E. (d) (1993). Olga Sumskaja: Ja yspytala orgazm dushy. [Kosnichuk E. Olga Sumskaya: I experienced an orgasm of the soul]. Kinokurier. № 15-16 (22-23). 3 (in Russian).

Kochevs'ka, L. (a) (1993). Ljubov Polischuk: "Dobrota - ce najsvjatishe!” [Kochevska L. Lyubov Polishchuk: "Kindness is the most sacred!") Kinokurier. №1 (8). 5 (in Ukrainian).

Kochevs'ka, L. (b) (1993). Myhajlo Svjetin: Ja vyris na Besarabci. [Kochevska L. Mykhailo Svetin: I grew up in Bessarabia]. Kinokurier. №11-12. (18-19). 6 (in Ukrainian).

Kucherjavyj, A. (1993). Alla Voloshyna: Bez zhyvoj very v Boga my podobny raznocvetnomu oknu v temnote... [Kucheryavy A. Alla Voloshina: Without a living faith in God, we are like a colorful window in the dark...]. Kinokurier. №6. 5 (in Russian).

L (nerozbirlyvo), Ju. (1993). U vyri pervisnyh instynktiv chy gra bez pravyl? [L (inaudible) Y. In the vortex of primitive instincts or a game without rules?]. Kinokurier. №4. 2 (in Ukrainian).

Lukyna, M. (2003). Tehnologyja yntervju. Uchebnoe posobye dlja vuzov. [Lukina M. Technology of interviews. A textbook for universities]. Moskow, 2003. http://evartist.narod.ru/text5/34.htm

Maryna Mogylevs'ka: Ja nikoly ne gubylasja pered kameroju. [Maryna Mohylevska: I never got lost in front of the camera]. Kinokurier. 1993. №3 (10). 5 (in Ukrainian).

Mithun: Skil'ky kohanok ne rahuvav. [Mithun: How many mistresses did not count]. Kinokurier.1993. № 11-12. 8 (in Ukrainian).

Natali Jegorovij telefonuvala Larysa Pletinko. (Larisa Pletinko called Natalia Egorova]. Kinokurier.1993. №2 (9). 5 (in Ukrainian). 
Oleksijenko, L. (1993). Stepan Oleksenko: za mystectvo treba borotysja! [Oleksienko L. Stepan Oleksenko: we must fight for art!]. Kinokurier. №3 (10). 5 (in Ukrainian).

Otkrovenyja Venery. [Revelations of Venus]. Kinokurier.1993. №. 9-10. 4 (in Russian).

Pletynko, L. (a) (1993). Yvar Kalnynysh: Ja ne zhdu, kogda prydet depressyja. [Pletinko L. Ivar Kalninish: I do not wait for depression to come]. Kinokurier. № 9-10.7 (in Russian).

Pletynko, L. (b) (1993). Monolog Prymadonny, uslyshannyj v otryvkah v gostjah u Yryny Metlyckoj. [Pletinko L. Monologue of the Prima Donna, heard in excerpts during a visit to Irina Metlitskaya]. Kinokurier. № 13-14. 7 (in Russian).

Pletynko, L. (v) (1993). Metr lytovskogo kyno Regymantas Adomajtys - nash gost. [Pletinko L. The master of Lithuanian cinema Regimantas Adomaitis is our guest]. Kinokurier. № 6.5 (in Russian).

Pletynko, L. (h) (1993). Sergej Zhygunov: Schaste dlja menja - preodolenye! Dubl pervyj. [Pletinko L. Sergei Zhigunov: Happiness for me is overcoming! Double first]. Kinokurier. №3 (10). 6 (in Russian).

Sofy Marso: Ljublju tanec, veter, solnce! [Sophie Marceau: I love dance, wind, sun!]. Kinokurier. 1993. №9-10. 4 (in Russian).

Tarasova, G. (1993). Tramvaj udachi. [Tarasova G. Tram of luck]. Kinokurier. №6. 4 (in Ukrainian).

Cybul'ko, R. (1993). Get' sorom! [Tsibulko R. Get rid of shame!]. Kinokurier. №9-10. 2 (in Ukrainian).

Chernova Yu. (1993) Dmytro Harat'jan: Ja povnistju v rukah fortuny. [Chernova Yu. Dmitry Kharatyan: I am completely in the hands of fortune]. Kinokurier. №2 (9). 5 (in Ukrainian).

\section{ОСОБЛИВОСТІ ІНТЕРВ'Ю В ГАЗЕТІ “КІНОКУР'СР” ЗА 1993 РІК Ганна Холод, кандидат філологічних наук, директор Громадської організації “Науково-освітній цеентр “УСПІШНИЙ” (м. Київ, Україна).}

Проблема. Стаття є продовженням дослідження прочесів деканонізащії жанру інтерв'ю на початку 90-х років XX століття. У ній з'ясовано специфіку інтерв'ю, розміщених у газеті “Кінокур'єр" (1993), завдяки аналізу матеріалів на змістовому, композиційному, образному, мовному, паралінгвістичному рівнях.

Методологія. Описовий метод дозволив зафіксувати все, щуо потрібно для висвітлення теми дослідження. Аналіз та синтез сприяли формуванню цілісного уявлення щодо специфіки контенту, композищї, оформлення, образної системи інтерв'ю, розміщених у газеті “Кінокур'єр” (1993). Об'єкт дослідження - інтерв'ю в газеті “Кінокур'єр” (1993 рік). Предмет дослідження - специфіка інтерв'ю в газеті “Кінокур'єр” (1993 рік). Мета дослідження - з'ясування особливостей інтерв'ю в газеті “Кінокур'єр” (1993 рік).

Висновки. Отже, у газеті “Кінокур'єр” (1993), крім класичних інтерв'ю з різною композиційною варіативністю й інтерв'ю-монологів, використано журналістські тексти, у яких домінантним є інтерв'ю і які мають такі модифікації: жанрову комбінацію, жанровий конгломерат, жанрову інкрустащію, щуо сприяють максимальній презентації образу інтерв'юйованого на змістовому, композиційному, мовленнєвому, паралінгвістичному рівнях. У журналістських текстах, де є інтерв'ю закордонного походження й текстові доповнення вітчизняних журналістів, діапазон розкриття образу інтерв'юйованого збільшується завдяки міжкультурному компонентові. 
Ключові слова: інтерв'юер, інтерв'юйований, журналістський текст, композиційні елементи, контамінація.

Submitted to the editorial office - 09.09. 2020

Reviewed-26.10.2020

Accepted for printing - 29.11.2020

Подано до редакиії-09.09.2020

Рецензовано - 26.10.2020

Прийнято до друку - 29.11.2020 